\title{
Salt-Stress Induced Protein Pattern Related to Seed Germination Indices in Lemon Balm (Melissa officinalis L.)
}

\author{
Roghayeh Dehghani ${ }^{2}$, Daryush Talei ${ }^{1}$, Tayebeh Radjabian ${ }^{2}$ \& Azra Saboora $^{3}$ \\ ${ }^{1}$ Medicinal Plants Research Center, Shahed University, Tehran, Iran \\ ${ }^{2}$ Department of Biology, Faculty of Basic Sciences, Shahed University, Tehran, Iran \\ ${ }^{3}$ Department of Plant Sciences, Faculty of Biological Sciences, Alzahra University, Tehran, Iran \\ Correspondence: Daryush Talei, Medicinal Plants Research Center, Shahed University, Tehran 3319118651, Iran. \\ Tel: 98-215-121-4093. Fax: 98-215-121-4092. E-mail: d.talei1348@gmail.com \\ Tayebeh Radjabian, Department of Biology, Faculty of Basic Sciences, Shahed University, Tehran, Iran. E-mail: \\ rajabian@shahed.ac.ir
}

$\begin{array}{ll}\text { Received: August 27, } 2017 & \text { Accepted: October 7, } 2017 \quad \text { Online Published: November } 15,2017 \\ \text { doi:10.5539/jas.v9n12p74 } & \text { URL: https://doi.org/10.5539/jas.v9n12p74 }\end{array}$

\begin{abstract}
Salinity is one of the major environmental stress factors that cause many adverse effects on growth and productivity of plants. The objective of the present study was to investigate the effects of salinity levels on seed germination indices and protein patterns in Melissa officinalis seedlings. An experiment was carried out based on randomized complete block design with five concentrations of $\mathrm{NaCl}$ and four replicates with sand medium. The results indicated that salt stress had negative effects on the seed germination percentage (GP), mean germination time (MGT) and germination rate (GR), primary shoot and root length, as well as the protein content. After two days of salt exposure, the lowest $(0 \%)$ GP was obtained for seeds treated with $12 \mathrm{dSm}^{-1}$ salinity, as compared to the control (48.5\%). Although, high salinity levels delayed seed germination, but during the experimental period GP increased and no significant differences were observed among the treatments in terms of GP after two weeks. The highest MGT (4.97 days) was obtained for plants stressed with $12 \mathrm{dSm}^{-1}$ salinity level, as compared to the control (1.89 days). Analysis of the protein bands revealed that salinity suppressed the expression of two proteins with the size of 45 (Y1), and $40 \mathrm{kDa}$ (Y2) and protein of $60 \mathrm{kDa}$ (D1) was down-regulated. Also, the synthesis of four proteins of $70(\mathrm{X} 1), 30(\mathrm{X} 2), 25$ (X3), and $20 \mathrm{kDa}(\mathrm{X} 4)$ was induced in the seedlings under salinity stress. The changes in protein pattern under salinity stress indicated that the synthesis of new proteins may be associated to the stress specific proteins.
\end{abstract}

Keywords: germination rate, mean germination time, Melissa officinalis, protein pattern, salinity

\section{Introduction}

Salinity is one of the most important environmental factors limiting crop production of marginal agricultural soils in many parts of the world (Abbasian \& Moemeni, 2013). More than 6\% of the total land area in the world and approximately $20 \%$ of the total agricultural lands are affected by salt. Sodium chloride is the predominant salt causing salinization, and it is unsurprising that plants have evolved mechanisms to regulate its accumulation (Keshavarzi et al., 2011). Approximately 15.2\% of surface area of Iran is affected by salinity (Rezaie et al., 2013). Seed germination and early seedling growth are critical stages for the establishment of the plant populations under saline conditions (Gulzar \& Khan, 2003; Zhang et al., 2010).

A high salt level interferes with the germination of seeds. Salinity and drought stresses have similar effects on plants, preventing roots from performing their osmotic activity where water and nutrients move from an area of higher concentration (the soil) into the roots. Therefore, because of the increased salt level in the soil, water and nutrients cannot move into the plant roots (Bojović et al., 2010). Salinity can affect growth and yield of most crops, high salinity is known to cause both hyper ionic and hyper osmotic effects in plants, leading to membrane disorganization, increase in reactive oxygen species production and metabolic toxicity (Abbasian \& Moemeni, 2013). The effects of salinity on all stages of plant growth have been mentioned. Soil salinity affects various physiological and biochemical processes which result in reduced biomass production. This adverse effect of salt stress appears on the entire plant at almost every stage of growth including germination, seedling development, 
vegetative and reproductive stages. However, tolerance to salt stress at each stage varies from species to species (Ratnakar \& Rai, 2014).

Anbumalarmathi and Mehta (2013) studied the response of eight indica rice (Oryza sativa var. indica) varieties to six salinity levels $\left(0,4,8,12,16\right.$ and $\left.20 \mathrm{dSm}^{-1}\right)$ at germination and early seedling growth stage and reported that salinity decreased the total germination percentage (TGP), speed of germination (SG) and germination energy percentage (GEP) and led to reduction in shoot and root length and dry weight in all varieties and the magnitude of reduction increased with increasing salinity stress.

Lemon balm (Melissa officinalis L.), is one of the important medicinal plant species in the family Lamiaceae that is blessed with bioactive compounds (Kim et al., 2010). Today, it is used in different branches of industry (such as medicine, perfume, cosmetic and food) in many countries of the world (Bagdat \& Cosge, 2012). The main components of the essential oil are citronellal (2-40\%) and citral (neral and geranial) $10-30 \%$, along with $\beta$-caryophyllene, germacrene D, ocimene and citronellol (Vaverková et al., 2012). It's essential oil is currently used in medicine and pharmacology as anti-tumor, anti-bacterial, anti-microbial, anti-histaminic, anti-spasmodic and anti-oxidant, by means of its antiviral effect curing the symptoms of herpes, anti-ulcerogenic, it helps to moderate Alzheimer's disease, acting modulation of mood and enhancing cognitive performance, stimulating the immune system (against HIV-1) and the heart. Essential oil obtained from aerial parts of plant is used to alleviate insect bites, painful menstruation, colds, headaches, mumps, insomnia, as a mild sedative and anti-depressant. In food industry, lemon balm essential oil is used for food spoilage yeasts to extend the storage periods; in soft drinks industry and herbal tea industries because of its fresh lemon taste and in cosmetic industry (for its hydrosol content) to cure some dermatological problems (Bagdat \& Cosge, 2012; Moradkhani et al., 2010).

The protein profiling study is an important alternative measurement of gene expression in plants; when this expression occurs in response to various abiotic stress conditions. Therefore, these results are necessary to examine the salt stress at the molecular level and to investigate the relationship between biomarkers (such as protein bands) and germination indices changes. Many proteins undergo post-translational modifications, which play an important role in their activity and subcellular allocation (Graves \& Haystead, 2002; Kettman et al., 2002). In this research, we demonstrate the impact of salinity on some germination indices in M. officinalis.

\section{Materials and Methods}

\subsection{Plant Materials}

Lemon balm seeds were provided from Medicinal Plants Research Center, Shahed University, Tehran, Iran.

\subsection{Experimental Design}

The experiment was carried out as a randomized complete block design (RCBD) with five salinity levels ( 0 (as control), 3, 6, 9 and $12 \mathrm{dSm}^{-1}$ ) and four replicates. Seeds were soaked in separate petri dishes in each level of treatment. The seeds were surface sterilized by soaking them in $10 \%(\mathrm{v} / \mathrm{v})$ sodium hypochlorite $(\mathrm{NaOCl})$ solution for $3 \mathrm{~min}$ and thoroughly rinsed with distilled water. Treatments were randomly assigned to the experimental units, and were distributed evenly on a Whatman paper (No. 1) placed into a sterile petri dish. Fifty seeds for each of the five $\mathrm{NaCl}$ treatments were used and $6 \mathrm{~mL}$ of $\mathrm{NaCl}$ solution in water were added into each petri dish and sealed with parafilm and were located in a controlled growth chamber in the laboratory of Medicinal Plants Research Center. Seeds were allowed to germinate in and the number of germinant seeds was counted every day up to 14 days and the seeds were considered germinated when the radical emerged. The average temperature of the growth chamber was set between $28-30{ }^{\circ} \mathrm{C}$ with relative humidity between $60-75 \%$. After two days, the germinated seeds were counted every day. And at the end of the experimental period of 14 days, the TGP (seeds germinated/total seeds $\times 100$ ) and average seed germination percentage (AGP) were then calculated. The mean germination time (MGT) was calculated using the described formula of Ellis and Roberts (1981) as follow:

$$
\mathrm{MGT}=\sum \mathrm{nD} / \sum \mathrm{n}
$$

Where, $\mathrm{n}=$ number of seeds newly germinated at time $\mathrm{D} ; \mathrm{D}=$ days from the beginning of the germination test; $\sum \mathrm{n}=$ final germination.

The germination rate (GR) was calculated by dividing the germination percentage obtained at each counting to the actual number of that particular counting day. The effects of the treatments were evaluated based on the germination percentage and time. The primary root and shoot length of each seedling was measured after 14 days. 
Analysis of variance of data was performed with SPSS version 22 and means were compared using Tukey's Multiple Range Test (TMRT).

\subsection{Protein Extraction and Estimation of Total Soluble Protein Content}

One gram of each the $M$. officinalis seedling samples was ground in liquid nitrogen using pre-cooled mortar and pestle to obtain a fine powder and then homogenized with extraction buffer $(20 \mathrm{mM} \mathrm{HEPES/KOH} \mathrm{pH} \mathrm{7.5,} 40$ $\mathrm{mM} \mathrm{KCl}, 1 \mathrm{mM}$ EDTA, 10\% (v/v) Glycerol and $1 \mathrm{mM}$ PMSF) as described by Talei et al. (2013). The supernatants were collected, and the total protein concentration was determined using the Bradford method (1976). Bovine serum albumin (Sigma-Aldrich, USA) was employed as a standard at $595 \mathrm{~nm}$, using a spectrophotometer (Perkin Elmer Lambda 25; UV/VIS, USA). The protein samples were run on SDS-PAGE electrophoresis separation following the method described in Laemmli (1970). Fifteen $\mu \mathrm{g}$ of the solubilized protein from each sample was loaded in each lane of the $12 \%$ concentrated separating gel. Electrophoresis was accomplished at $100 \mathrm{~V}$ over 90 minutes using a Bio-Rad, Mini Protein electrophoresis system (Bio-Rad, USA). The observed protein bands were scored using the UVIDoc Analyzer software (UVIDoc, Houston, Texas, USA).

\section{Results and Discussion}

From the results in Table 1 it can be seen that salinity levels had significant $(P \leq 0.01)$ effects on the seed germination percentage (GP), mean germination time (MGT) and germination rate (GR). After two days of salt exposure, the highest $(48.5 \%)$ and the lowest $(0 \%)$ germination percentages were obtained for control seeds and seeds treated with $12 \mathrm{dSm}^{-1}$ salinity level, respectively. Exposing the seeds to salinity showed that increasing the salinity levels led to significant decrease in the germination percentage and germination rate, as well as the primary shoot and root lengths. Although high salinity delayed initiation of seed germination, during the experimental period germination percentage increased and no significant differences were observed among the treatments in terms of GP after two weeks. The results of the data mean comparisons indicated that there were significant differences among salinity levels in terms of MGT, so that the lowest (1.89 days) and the highest (4.97 days) values for this index were obtained for control seeds and seeds treated with $12 \mathrm{dSm}^{-1}$ salinity level, respectively. The primary shoot and root length significantly decreased with increasing salinity levels.

Table 1. Variance analysis of some germination and growth of seedling characteristics of $M$. officinalis under salinity stress

\begin{tabular}{lllllllll}
\hline \multirow{2}{*}{ Source of variance } & \multirow{2}{*}{ df } & \multicolumn{7}{c}{ Mean Square } \\
\cline { 3 - 8 } & & GP $(\%)$ & TGP $(\%)$ & MGT (min) & AGP $(\%)$ & GR & RL $(\mathrm{cm})$ & SL $(\mathrm{cm})$ \\
\hline Replication & 3 & $27.33^{\text {ns }}$ & $30.067^{7^{\mathrm{ss}}}$ & $0.104^{\text {ns }}$ & $22.707^{\text {ns }}$ & $11.789^{\text {ns }}$ & $0.023^{\text {ns }}$ & $0.012^{\text {ss }}$ \\
Salinity levels & 4 & $1759.70^{* *}$ & $20.8^{\text {ns }}$ & $5.735^{* *}$ & $284.428^{* *}$ & $135.115^{* *}$ & $3.363^{* *}$ & $2.883^{* *}$ \\
Test error & 12 & 14.50 & 33.067 & 0.059 & 44.345 & 24.615 & 0.024 & 0.008 \\
\hline
\end{tabular}

Note. ** and ns, refer to $1 \%$ and not significant, respectively. GP: germination percentage at 2 day, TGP: total germination percentage at 14 day, MGT: mean germination time at 14 day, AGP: average germination percentage at 14 day, GR: germination rate at 14 day, RL: root length, SL: shoot length.

Germination is a dynamic process in the life cycle of plants while the seed undergoes a rapid transition from a state of dormancy to a metabolically active seedling. Seed is one of the important organs of a plant which plays a crucial role in the continuation of the race. The sequence of germination follows simple events such as imbibition of water, enzyme activation, and hydrolysis of stored material, initiation of growth, rupture of seed coat and emergence of the seedling. According to Siti Aishah et al. (2010), salinity adversely affects germination by decreasing the osmotic potential of the soil solution to such a point that it prevents the intake of water. Salinity may even produce toxic effects on the embryo and the seedlings which results in delayed germination and or reduced percentage germination, which may be true even in the present study.

According to Begum et al. (2010), germination of seed depends on the utilization of reserved food materials of the seed. Salinity interferes with the process of water absorption by the seeds. This subsequently inhibits the hydrolysis of seed reserves which ultimately delays and decreases seed germination. The findings of this study indicated that salinity levels had significant effect on some germination indices, such as GP, MGT and GR. In agreement with the reports of Bagheri et al. (2012) on Thymus species and Siti Aishah et al. (2010) on forage sorghums, who showed that increasing of salinity led to decrease in GP, GR, plumule and radicle lengths, the findings of this study indicated that salinity level was an important factor affecting the GP and GR, as well as the 
primary shoot and root lengths. This may be due to the negative effects of salt stress on water absorption, nutrient uptake and osmotic imbalance in the environment of plumules and radicles, ion toxicity and ultimately reduction in GP and GR, and finally led to a significant reduction in seedling emergence and plant establishment. Although, the high salinity caused delay on seed germination, but during the experimental period, germination percentage increased, and no significant differences were observed among the treatments in terms of GP after two weeks. The mean comparison of the treatments showed that the MGT was the lowest in control (1.89 days) and reached to a maximum value (4.97 days) at $12 \mathrm{dSm}^{-1}$ salinity level (Figure 1).

The Root and shoot lengths are the most important parameters for studying salt stress, as roots have direct contact with soil. In the present investigation, the primary shoot and root length significantly decreased with increasing salinity levels, which matched up well with the findings of Jaleel et al. (2008), who showed that salt stress decreased root length in Catharanthus roseus. This may be due to the negative effects of salt stress on water absorption and disproportion of nutrient absorption by the seedlings, as suggested by Bybordi and Tabatabaei (2009). Similarly, Nyagah and Musyimi (2009) observed a reduction in growth in passion fruit (Passiflora edulis) seedlings with increasing concentrations of salt in the medium.
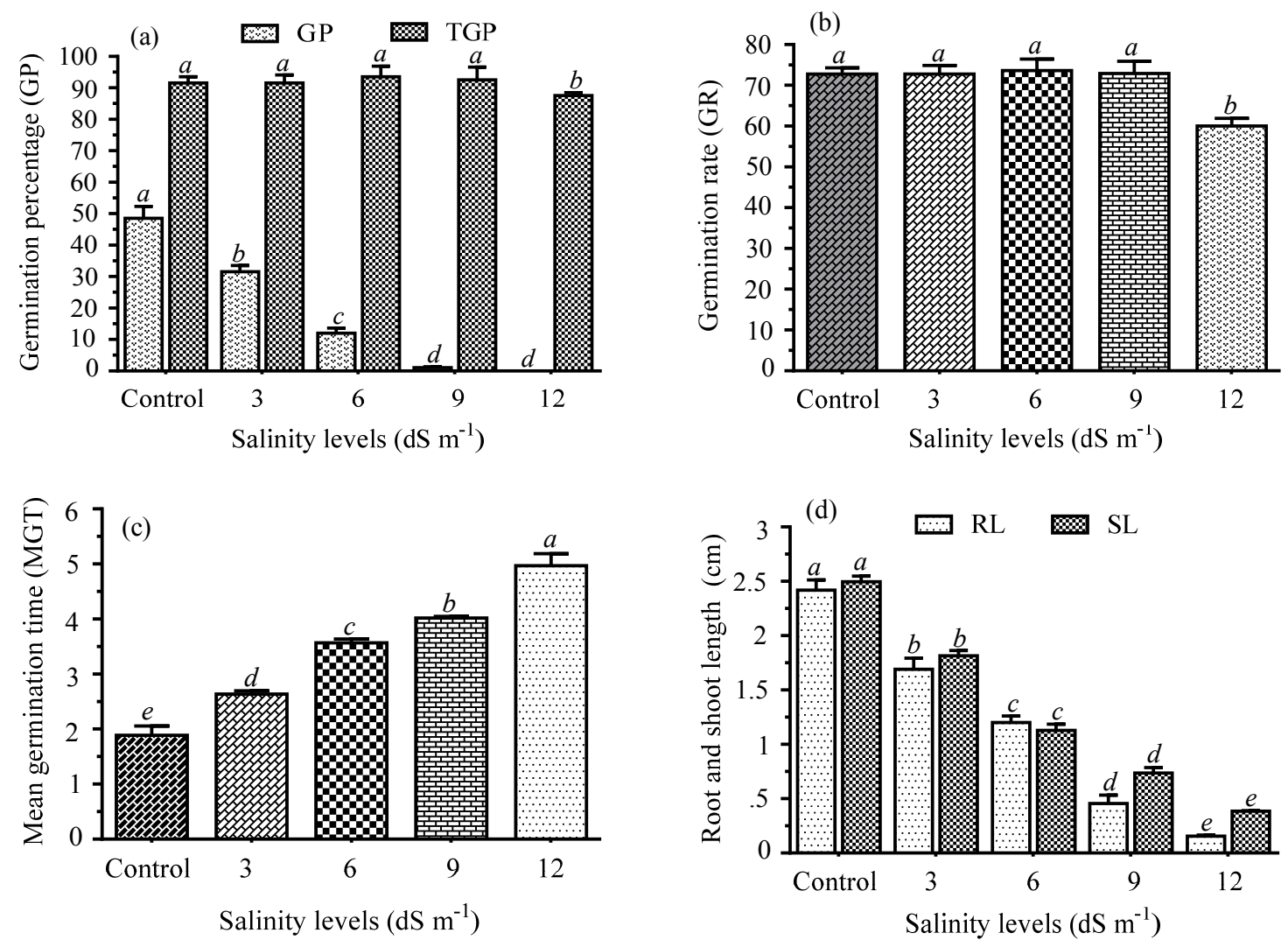

Figure 1. The effect of different salinity levels on germination percentage (GP) at day 2 and total germination percentage (TGP) at day 14 (a), germination rate (GR) at day 14 (b), mean germination time (MGT) at day 14 (c) and root (RL) and shoot (RL) length at day $14(\mathrm{~d})$. Mean values \pm SE are from three independent replicates and

values superscripted by different letters are significantly different by Tukey's multiple range test $(\mathrm{P} \leq 0.01)$

\subsection{Seedling Protein Pattern}

In the present study, a significant salt-induced alteration in the protein expression profiles of primary roots and shoots of seedlings was noticed (Figure 2). The results of SDS-PAGE protein profile revealed that there were qualitative and quantitative differences in protein profiles between samples under different salinity levels. As shown in Figure 2, fifteen protein bands with a wide range of molecular masses from 10-120 kDa were detected. The results of SDS-PAGE protein profile indicated that there were obvious qualitative and quantitative differences in protein patterns between control and salt-stressed samples. Salinity inhibited the synthesis of two protein bands with the size of $45 \mathrm{kDa}$ (protein $\mathrm{Y}_{1}$ ), and $40 \mathrm{kDa}$ (protein $\mathrm{Y} 2$ ). Interesting to note that, salt 
treatment enhanced the synthesis of four new protein bands having MW of $70 \mathrm{kDa}$ (protein X1), $30 \mathrm{kDa}$ (protein $\mathrm{X} 2$ ), $25 \mathrm{kDa}$ (protein X3), and $20 \mathrm{kDa}$ (protein X4), which completely were absent in controlled condition. The results suggested that these four induced protein bands might be related to the seed germination indices. As protein samples were loaded in equal amounts of $15 \mu \mathrm{g}$ in all cases, the results showed that protein bands of "Y1 and Y2" were not found in the highest salinity level $\left(12 \mathrm{dSm}^{-1}\right)$, while there were found the protein bands of "X1 to X4". Also, density the protein band of "D1" $(60 \mathrm{kDa})$ was visibly reduced at the maximum salinity level.

Differential expression of polypeptides in the primary shoots and roots of salt-stressed $M$. officinalis seedlings in the present study, probably indicating the molecular adaptive mechanism of those to osmotic stress. Protein profiles in revealed that seeds grown under salinity conditions encountered with induction or repression in the synthesis of a few polypeptides.

During the experimental period GP increased but no significant differences were observed among the salinity levels in terms of GP at day 14. This could be related to the expression of new four induced proteins for salt tolerance of seedlings during the experimental period. In accordance with our results, the reports of Khedr et al. (2003) on Pancratium maritimum, Meratan et al. (2008) on Vicia faba seeds, and Mohsen et al. (2013) on Acanthophyllum species proved the increase of protein content and polypeptide bands under salt treatment. The observation of new low molecular weight proteins, specially a $25 \mathrm{kDa}$ protein in the present study, which may be were specific to adaptation to salt stress was confirmed by the earlier report of Gomathi et al. (2013) on sugarcane. Analysis of the proteomes of many plant species under salinity conditions has revealed that they can respond to salt stress by high-regulating (especially osmotin-like proteins and heat shock proteins) or low-regulating (especially photosynthesis-related proteins) of specific proteins. Heat shock proteins and osmotin-like proteins are the most well-known stress-related proteins in plants and their expression is mostly observed in the salt-tolerant plants under salt stress (Sobhanian et al., 2011).

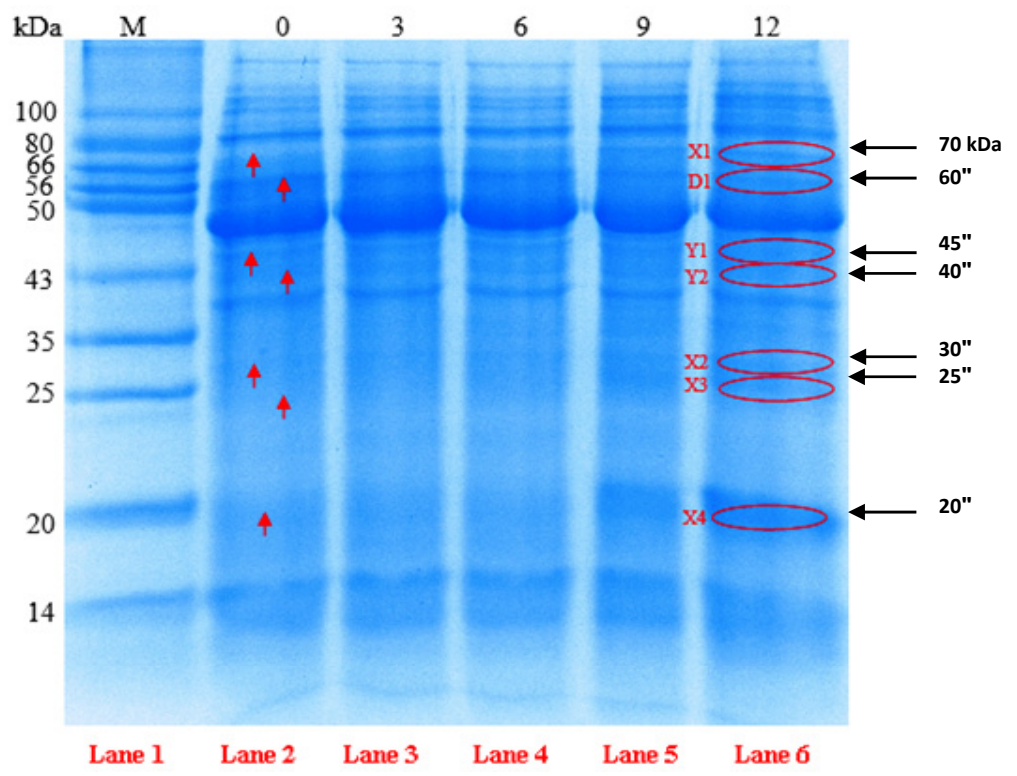

Figure 2. SDS-PAGE profile of total protein extracts from seedlings of $M$. officinalis on $12 \%$ polyacrylamide gel. The lane 1 represents protein molecular weight marker, and the lanes of 2-6 represent protein samples at different salinity levels $\left(0,3,6,9\right.$, and $\left.12 \mathrm{dSm}^{-1}\right)$. Protein samples were loaded with equal amount of $15 \mu \mathrm{g}$. The "Y1 and

$\mathrm{Y} 2$ " proteins were not found at high salinity level $\left(12 \mathrm{dSm}^{-1}\right)$, and four bands corresponding to "X1 to X4" proteins were detected at $12 \mathrm{dSm}^{-1}$ salinity level, and the protein band "D1" was low-regulated at high salinity level

According to Zhang et al. (2012), abiotic stresses such as salinity have harmful effects on the structure of proteins and their function in plant cells and could potentially damage proteins. The disappearance of proteins in response to $\mathrm{NaCl}$-based salinity has been observed in wheat (El-Shintinawy \& El-Shourbagy, 2001) and Bruguiera parviflora (Parida et al., 2004). In agreement with the reports of and Talei et al. (2015), the findings 
of this study indicated that the protein amounts of salt-treated plants were decreased, possibly due to the changes in the ratio of the lipoprotein of pigment protein complexes and/or chlorophyllase activity. Our results also matched up well with the findings of Nazarpour et al. (2017), who showed that salt stress decreased the germination percentage of $M$. officinalis. Electrophoresis information on the primary shoot and root proteins can be specifically matched with the seed protein data (Talei et al., 2014) of $M$. officinalis to make fruitful decisions on the breeding programs. Consequently the salinity level significantly affected the germination indices, primary shoot and root length in Melissa officinalis.

The findings of this study in the entire measured traits indicated that salt stress adversely affected the germination rate and mean germination time of the $M$. officinalis seeds, as well as shoot and root lengths; however no absolute inhibition was observed in total germination percentages of the seeds at different salinity levels. Furthermore, salt-stress induced alterations in protein profiles of primary roots and shoots of the seedlings. Present experiment proved that the specific enhanced expression of some polypeptides was associated with salt tolerance in $M$. officinalis. Protein sequencing and proteomic analysis can be conducted based on the present findings, in the future. It can be concluded that salinity stress significantly affected all the studied seed germination and growth parameters of $M$. officinalis and this information should be taken into consideration when a medicinal plant grown under saline condition.

\section{References}

Abbasian, A., \& Moemeni, J. (2013). Effects of salinity stress on seed germination and seedling vigor indices of two halophytic plant species (Agropyron elongatum and A. pectiniforme). International Journal of Agriculture and Crop Sciences, 5(22), 2669-2676.

Anbumalarmathi, J., \& Mehta, P. (2013). Effect of salt stress on germination of indica rice varieties. OnLine Journal of Biological Sciences, 6(1), 1-6.

Bagdat, R. B., \& Cosge, B. (2012). The essential oil of lemon balm (Melissa officinalis L.), its components and using fields. Anadolu Journal of Agricultural Sciences, 21(1), 116-121.

Bagheri, M., Yeganeh, H., Bandak, E., \& Ghasemi, A. Y. (2012). Effects of salinity stress on seed germination characteristics of two medicinal species Thymus kotschyanus and T. daenensis. Journal of Rangeland Science, 2(2), 507-512.

Begum, F., Ahmed, I., Nessa, A., \& Sultana, W. (2010). The effect of salinity on seed quality of wheat. Journal of the Bangladesh Agricultural University, 8(1), 19-22. https://doi.org/10.3329/jbau.v8i1.6392

Bojović, B., Delić, G., Topuzović, M., \& Stanković, M. (2010). Effects of $\mathrm{NaCl}$ on seed germination in some species from families Brassicaceae and Solanaceae. Kragujevac Journal Science, 32, 83-87.

Bradford, M. M. (1976). A rapid and sensitive method for the quantitation of microgram quantities of protein utilizing the principle of protein-dye binding. Analytical Biochemistry, 72(1-2), 248-254. https://doi.org/ 10.1016/0003-2697(76)90527-3

Bybordi, A., \& Tabatabaei, J. (2009). Effect of salinity stress on germination and seedling properties in canola cultivars (Brassica napus L.). Notulae Botanicae, Horti Agrobotanici, Cluj-Napoca, 37(2), 71-76.

Ellis, R. H., \& Roberts, E. H. (1981). The quantification of ageing and survival in orthodox seeds. Seed Science Technology, 9, 373-409.

El-Shintinawy, F., \& El-Shourbagy, M. (2001). Alleviation of changes in protein metabolism in NaCl-stressed wheat seedlings by thiamine. Biologia Plantarum, 44(4), 541-545. https://doi.org/10.1023/A:10137386 03020

Gomathi, R., Vasantha, S., Shiyamala, S., \& Rakkiyappan, P. (2013). Differential accumulation of salt induced proteins in contrasting sugarcane genotypes. European Journal of Biological Sciences, 6, 7-11.

Graves, P. R., \& Haystead, T. A. J. (2002). Molecular biologist's guide to proteomics. Microbiology and Molecular Biology Reviews, 66(1), 39-63. https://doi.org/10.1128/MMBR.66.1.39-63.2002

Gulzar, S., \& Khan, M. (2003). Germination responses of Sporobolus ioclados: A potential forage grass. Journal of Arid Environments, 53, 387-394. https://doi.org/10.1006/jare.2002.1045

Jaleel, C. A., Sankar, B., Sridharan, R., \& Panneerselvam, R. (2008). Soil salinity alters growth, chlorophyll content, and secondary metabolite accumulation in Catharanthus roseus. Turkish Journal of Biology, 32, $79-83$. 
Keshavarzi, M., Mehrnaz, S., Ohadi, R., Mohsen, M., \& Amir, L. (2011). Effect of salt (NaCl) stress on germination and early seedling growth of Spinach (Spinacia oleracea L.). Annals of Biological Research, 2(4), 490-497.

Kettman, J. R., Coleclough, C., Frey, J. R., \& Lefkovits, I. (2002). Clonal proteomics: One gene-family of proteins. Proteomics, 2(6), 624-631. https://doi.org/10.1002/1615-9861(200206)2:6\%3C624::AID-PROT $624 \% 3 \mathrm{E} 3.0 . \mathrm{CO} ; 2-\mathrm{I}$

Khedr, A. H. A., Abbas, M. A., Wahid, A. A. A., Quick, W. P., \& Abogadallah, G. M. (2003). Proline induces the expression of salt stress responsive proteins and may improve the adaptation of Pancratium maritimum L. to salt stress. Journal of Experimental Botany, 54(392), 2553-2562. https://doi.org/10.1093/jxb/erg277

Kim, S., Yun, E. J., Bak, J. S., Lee, H., Lee, S. J., Kim, C. T., ... Kim, K. H. (2010). Response surface optimised extraction and chromatographic purification of rosmarinic acid from Melissa officinalis leaves. Food Chemistry, 121(2), 521-526. https://doi.org/10.1016/j.foodchem.2009.12.040

Laemmli, U. K. (1970). Cleavage of structural proteins during the assembly of the head of bacteriophage T4. Nature, 227(5259), 680-685. https://doi.org/10.1038/227680a0

Meratan, A., Ghafari, S. M., \& Niknam, V. (2008). Effects of salinity on growth, proteins and antioxidant enzymes in three Acanthophyllum species of different ploidy levels. Journal of Science (University of Tehran) (JSUT), 33(4), 1-8.

Mohsen, A. A., Ebrahim, M. K. H., \& Ghoraba, W. F. S. (2013). Effect of salinity stress on Vicia faba productivity with respect to ascorbic acid treatment. Iranian Journal of Plant Physiology, 3(3), 725-736.

Moradkhani, H., Sargsyan, E., Bibak, H., Naseri, B., Sadat-Hosseini, M., Fayazi-Barjin, A., \& Meftahizade, H. (2010). Melissa officinalis L., a valuable medicine plant: A review. Journal of Medicinal Plants Research, 4(25), 2753-2759.

Nozarpour, E., Afshari, R. T., Soltani, E., \& Hosseini, N. M. (2017). The effects of salinity and temperature on germination responses of lemon balm (Melissa officinalis L.). Iranian Journal of Field Crop Science, 47(4), 689-699.

Nyagah, A., \& Musyimi, D. (2009). Effects of sodium chloride solution stress on germination and growth of passion fruits seedlings. ARPN Journal of Agricultural and Biological Science, 4, 49-53.

Parida, A. K., Das, A. B., \& Mohanty, P. (2004). Defense potentials to $\mathrm{NaCl}$ in a mangrove, Bruguiera parviflora: Differential changes of isoforms of some antioxidative enzymes. Journal of Plant Physiology, 161(5), 531-542. https://doi.org/10.1078/0176-1617-01084

Ratnakar, A., \& Rai, A. (2014). Improvement of Salt Tolerance in Trigonella foenum-graecum L. var. PEB by Plant Growth Regulators. Journal of Stress Physiology and Biochemistry, 10(2), 135-143.

Rezaie, E. E., Haghighikhah, M., Ghorbani, S., \& Kafi, M. (2013). Effect of seed priming on seed germination properties of two medicinal species in the presence of salinity. Journal of Medicinal Plants Research, 7(18), 1234-1238.

Siti Aishah, H., Saberi, A. R., Halim, R. A., \& Zaharah, A. R. (2010). Salinity effects on germination of forage sorghumes. Journal of Agronomy, 9(4), 169-174. https://doi.org/10.3923/ja.2010.169.174

Sobhanian, H., Aghaei, K., \& Komatsu, S. (2011). Changes in the plant proteome resulting from salt stress: toward the creation of salt-tolerant crops? Journal of Proteomics, 74(8), 1323-1337. https://doi.org/10.1016/ j.jprot.2011.03.018

Talei, D., Valdiani, A., \& Abdullah, M. P. (2014). Impact of protein diversification on morphometric behavior of Andrographis paniculata Nees. Plant Systematics and Evolution, 300, 1003-1010. https://doi.org/10.1007/ s00606-013-0938-z

Talei, D., Valdiani, A., \& Puad, M. (2013). An effective protein extraction method for two-dimensional electrophoresis in the anticancer herb (Andrographis paniculata Nees.). Biotechnology and Applied Biochemistry, 60(5), 521-526. https://doi.org/10.1002/bab.1126

Talei, D., Valdiani, A., Maziah, M., Sagineedu, S. R., \& Abiri, R. (2015). Salt stress-induced protein pattern associated with photosynthetic parameters and andrographolide content in Andrographis paniculata Nees. Bioscience, Biotechnology, and Biochemistry, 79(1), 51-58. https://doi.org/10.1080/09168451.2014.963499 
Vaverková, Š., Mistríková, I., \& Farkaš, P. (2012). Qualitative properties of Melissa officinalis after the application of Rastim 30 DKV. Botanica Serbica, 36(2), 81-84.

Zhang, H., Irving, L. J., McGill, C., Matthew, C., Zhou, D., \& Kemp, P. (2010). The effects of salinity and osmotic stress on barley germination rate: sodium as an osmotic regulator. Annals of Botany, 106(6), 1027-1035. https://doi.org/10.1093/aob/mcq204

Zhang, J., Guo, Q., Feng, Y., Li, F., Gong, J., Fan, Z., \& Wang, W. (2012). Manipulation of monoubiquitin improves salt tolerance in transgenic tobacco. Plant Biology, 14(2), 315-324. https://doi.org/10.1111/ j.1438-8677.2011.00512.x

\section{Abbreviation}

AGP: average germination percentage; GEP: germination energy percentage; MGT: mean germination time; GP: germination percentage; GR: germination rate; RL: root length; SL: shoot length; SDS-PAGE: sodium dodecyl sulfate polyacrylamide gel electrophoresis; SG: speed of germination; TGP: total germination percentage.

\section{Copyrights}

Copyright for this article is retained by the author(s), with first publication rights granted to the journal.

This is an open-access article distributed under the terms and conditions of the Creative Commons Attribution license (http://creativecommons.org/licenses/by/4.0/). 